This item was submitted to Loughborough's Research Repository by the author.

Items in Figshare are protected by copyright, with all rights reserved, unless otherwise indicated.

\title{
Information technology offshoring in India: a postcolonial perspective
}

PLEASE CITE THE PUBLISHED VERSION

http://dx.doi.org/10.1057/ejis.2012.32

\section{PUBLISHER}

(c) Operational Research Society Ltd. Published by Palgrave Macmillan

\section{VERSION}

AM (Accepted Manuscript)

\section{LICENCE}

CC BY-NC-ND 4.0

\section{REPOSITORY RECORD}

Ravishankar, M.N., Shan L. Pan, and Michael D. Myers. 2019. "Information Technology Offshoring in India: A Postcolonial Perspective". figshare. https://hdl.handle.net/2134/14661. 
This item was submitted to Loughborough's Institutional Repository (https://dspace.lboro.ac.uk/) by the author and is made available under the following Creative Commons Licence conditions.

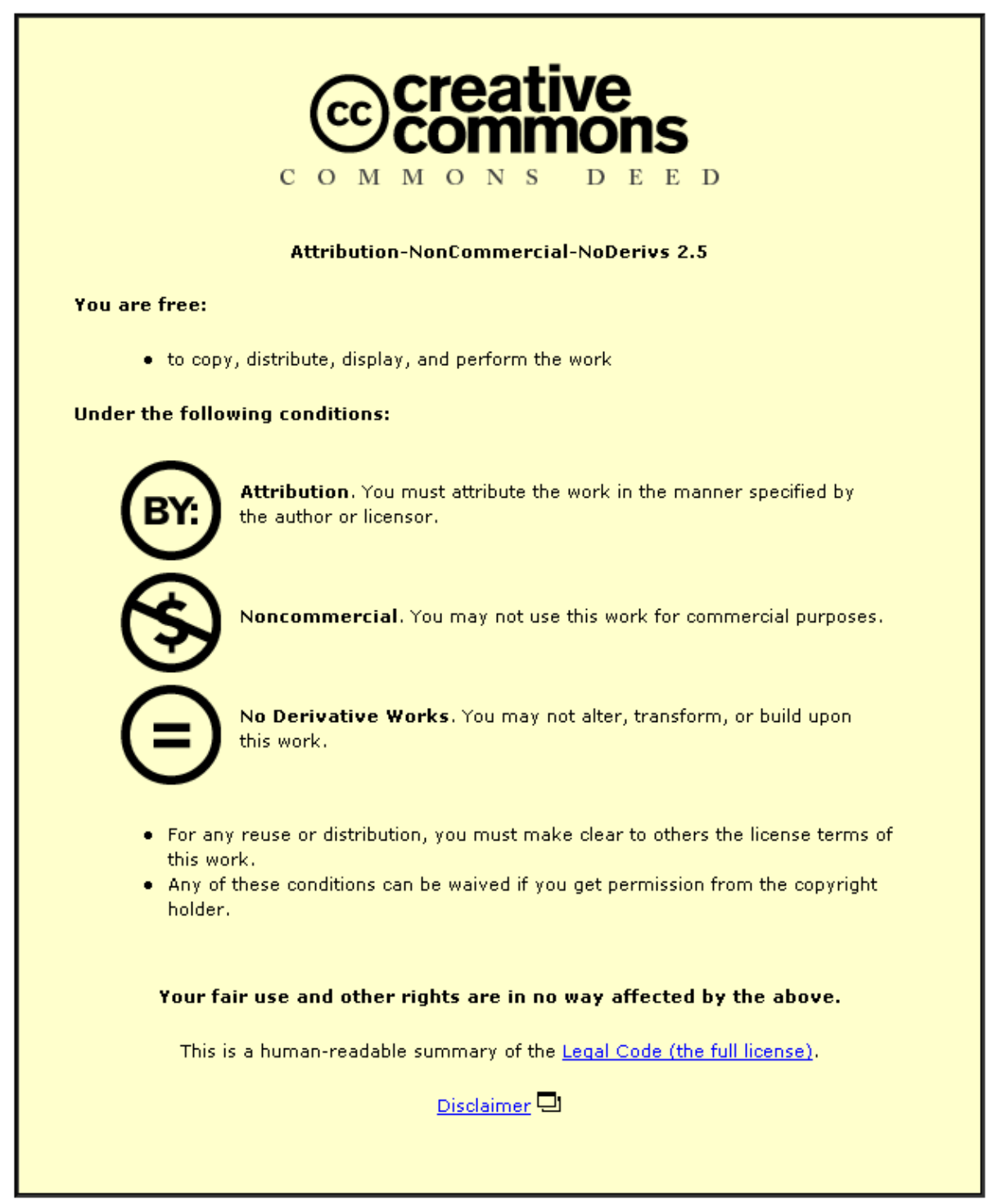

For the full text of this licence, please go to: http://creativecommons.org/licenses/by-nc-nd/2.5/ 


\title{
Information Technology Offshoring in India: A Postcolonial Perspective
}

\author{
M.N. Ravishankar, Shan L. Pan and Michael D. Myers
}

\begin{abstract}
In recent years India has become the information technology (IT) offshoring destination of choice for many Western organizations. From the perspective of vendor organizations in India, however, the IT offshoring phenomenon is more than just a business relationship with Western firms. It is also embedded within the context of the longstanding imbalances of power in the relationship between the West and the East, the implications of which have been largely ignored in empirical work on offshoring within the information systems (IS) discipline. Drawing on concepts from postcolonial theory and using data from our ethnographic fieldwork, we explore the experiences and responses of one Indian vendor organization to asymmetries of power in its relationship with Western client organizations. Our analysis demonstrates how a postcolonial reading and interpretation of IT offshoring adds an important new dimension to previous IS research and also helps to develop a more comprehensive understanding of the strategies deployed by vendor organizations.
\end{abstract}

Keywords: Critical Research, IT offshoring, Postcolonial theory, India, Ethnography 


\section{Introduction}

One of the main drivers for IT offshoring is the lower cost of operations in emerging economies. Other drivers include the rapid expansion of the telecommunications system during the dot-com boom and the digitization of work processes (Aspray, et al., 2006). Lower telecommunications costs, world scale logistics, liberalization policies of governments, large pools of English-speaking engineering graduates and lower costs for air travel have all contributed to the success of the IT offshoring phenomenon (see Friedman, 2005; Nilekani, 2009). One way to look at the growth of the IT offshoring phenomenon is to view it as a logical progression from IT outsourcing (Lacity \& Hirschheim 1995; Hirschheim, et al., 2002; Mudambi \& Venzin, 2010). IT offshoring, however, takes outsourcing one step further. IT offshoring involves transferring the provision of IT services, not just to another company, but to a company in a foreign country (Apte \& Mason, 1995; Lacity \& Willcocks, 2001; Contractor et al., 2010) ${ }^{1}$.

Perhaps the country whose name is most often mentioned in this context is India, which has become one of the leading providers of IT offshoring services. According to recent estimates, the Indian IT offshoring services segment grew 19\% year-on-year with export revenues touching USD 40 billion (Nasscom, 2012). The last two decades have seen the establishment and impressive growth of a number of Indian IT services vendor organizations (Dossani \& Kenney, 2007; Joshi \& Mudigonda, 2008). Within the IS literature, taking the perspective of such vendor organizations and their employees, empirical research has considered several key issues surrounding the offshoring of IT services (e.g., Heeks, 1990, 1999; Nicholson \& Sahay, 2004; D’Mello \& Sahay, 2007; Oshri et al., 2007; Ravishankar \& Pan, 2008). While it is inaccurate to view all research from a vendor perspective as similar, generally speaking, a common strand runs through them. Typically they describe, explore and explain the important individual, organizational and industry level structures and capabilities, whose creation and coordination across space and time by the vendors ensure the effective delivery of services to client organizations in the Western world. For instance, studies have shown how vendors create industry-level professional bodies (Kshetri \& Dholakia, 2009), build strong leadership teams (Friedman, 2005), develop complementary sets of core competencies (Levina \& Ross, 2003), implement effective knowledge management (KM) strategies (Garud \& Kumaraswamy, 2005; Oshri et al., 2007) and grapple with

\footnotetext{
${ }^{1}$ In many multi-national corporations, the term IT offshoring is used to refer to the transfer of IT tasks to their own subsidiary or ('captive') unit in a different country.
} 
communication and cultural issues (Krishna et al., 2004; Nicholson \& Sahay, 2004; Ravishankar et al., 2011) in order to offer better services to client organizations.

On the whole, this stream of literature recognizes IT offshoring as a particular expression of globalization and also provides empirical insights into Indian vendors' attempts to meet their strategic goals through the implementation of several globally validated management practices and processes. Despite the obvious strengths of the various conceptual tools and frameworks employed in the extant literature, however, there remains an important gap. The IS literature very rarely takes into consideration one unique feature of IT offshoring, which has the potential to add an important new dimension to our understanding of offshore work. This concerns the extent to which the historically derived power-related asymmetries in the relationship between the West and India impact the ways in which Indian vendor organizations function, experience and respond to the offshoring relationships with their Western client organizations. In related academic disciplines such as organization studies, psychology, international business and industrial relations, recent research on offshore work has suggested that asymmetries of power grounded in history introduce a certain precariousness and anxiety into such relationships (Cohen \& El-Sawad, 2007; Frenkel, 2008; Zimmermann \& Ravishankar, 2011). The resulting fragility inevitably raises questions about how vendor organizations operating in highly globalized contexts and relying almost entirely on Western client organizations for business go about experiencing and negotiating historically embedded relations of power (see D'Mello, 2005; Cohen \& El-Sawad, 2007; Frenkel, 2008; Mir \& Mir, 2009).

While there is increasing mention of these issues in the popular media (see Lacity \& Rudramuniyaiah, 2009), empirical research in the IS discipline is still at a nascent stage. This paper is an attempt to address this gap. We draw on an in-depth interpretive ethnographic study (Klein \& Myers, 1999; Myers, 1999) of Indshore (a pseudonym), a large and wellknown Indian IT services vendor organization. Ethnographic research is one of the most indepth research methods possible and allows a researcher to get "where the action is" (Myers, 1999). In our case, it allowed us to develop an intimate familiarity with a globally recognized Indian IT services organization and the nature of its relationships with Western clients. Our main research question is: How do Indian IT services vendor organizations experience and respond to power asymmetries in their relationships with Western client organizations? In answering this question, we draw on postcolonial theory, which is a macro-framework that draws attention to asymmetrical power relations and their nexus with historical processes. 
This paper is organized as follows. In the next section, we discuss postcolonial theory. We then provide a brief review of the IT offshoring literature with specific reference to organizational initiatives amenable to postcolonial analysis. This is then followed by the research methods section. Next, the case of Indshore is presented and analyzed. The final section is the discussion and conclusions.

\section{Postcolonial theory}

Postcolonial theory "involves a studied engagement with the experience of colonialism and its past and present effects, both at the local level of ex-colonial societies as well as at the level of more general global developments thought to be the after-effects of empire" (Quayson, 2000, p.2) ${ }^{2}$. Young (2001, p.57) says that postcolonialism "marks the broad historical facts of decolonization and the determined achievement of sovereignty - but also the realities of nations and peoples emerging into a new imperialistic context of economic and sometimes political domination." Postcolonial theory is thus in effect a sub-set of critical theory (Kvasny \& Richardson, 2006; Richardson \& Robinson, 2007) and as such draws attention to larger concerns (e.g. issues of global asymmetric power relations) that are often missed in other kinds of research projects (Myers \& Klein, 2011). Although postcolonial theory has its roots in the humanities and literary studies where it is seen as a macro theory dealing with historical conditions of domination-subjugation and cultural identity, over the past decade management scholars have successfully demonstrated how it can be usefully applied as a nuanced analytical lens at the organizational level (Prasad, 2003; Frenkel, 2008; Ozkazanc-Pan, 2008). In several business and management disciplines, researchers have approached their fieldwork with postcolonial sensibilities, applying strands of postcolonial theory to understand experiences within and across organizations (see Frenkel \& Shenhav, 2003; Cohen \& El-Sawad, 2007; Mir \& Mir, 2009). For instance, in Marketing, a recent study of Indian business schools by Varman and Saha (2009) drew on a postcolonial critique to show how doctoral research projects largely mimicked Western concepts and ignored local stakeholders. In Organization Studies, an ethnographic study by Mir and Mir (2009) showed how deeper and hegemonic aspects of power helped an American MNC take full credit for a low cost product development technique developed by an offshore Indian contractor. Using a postcolonial framework, this study also revealed the subtle defiant practices adopted by the offshore employees to counteract the power imbalances. More

\footnotetext{
${ }^{2}$ It should be noted that this definition of postcolonialism is purely descriptive, not evaluative. That is, we are using this term in a neutral way to describe a particular historical situation; we are not using this term to imply that postcolonialism is either good or bad (see Prasad, 2003).
} 
recently, Mckenna (2011) applied postcolonial theory to demonstrate how business leaders in North American organizations represented China and India as "developing and progressing towards a North American ideal" while at the same time indicting these countries for their regressive practices. In International Management research, Frenkel (2008) has provided several good examples of how asymmetric power relations are central to mechanisms of knowledge transfer from MNC headquarters to foreign subsidiaries. She has also impressed upon the need to give more respect and recognition to the strategic and cultural capabilities of the subsidiary units. In a nutshell, it is clear from extant research that the dynamics of unequal colonial-style power relations and the collectively organized responses to such power imbalances are two key constructs of interest within postcolonial theory.

\section{Can we apply postcolonial theory when Western-European countries and organizations are not involved?}

While at first glance the term 'postcolonial theory' might suggest a narrow engagement of the East with the original Western European colonial powers, in the context of globalization its mandate is much wider. For example, it has been applied to better understand the asymmetric relations between the developing countries of Eastern Europe with the wider Western world (see Kuus, 2004). The theory grounds studies "in the historical context of colonialism, as well as in the political context of contemporary problems of globalization" (Brydon, 2000, p1-2). In its broadest sense it represents an attempt to investigate the complex and the deeply fraught dynamics of the relationship between the wider West and the non-West (Prasad, 2003). As Ashcroft (2001, p.208) writes, "we cannot understand globalization without understanding the structure of global power relations which flourishes in the twenty-first century as an economic, cultural and political legacy of Western imperialism." Postcolonial theory incorporates different dynamics of the unequal power relations between organizations of the once colonized countries and organizations of the West, including most notably the USA. For instance, as Frenkel and Shenhav (2003, p1538) note in their fascinating account of the diffusion of 'powerful' American productivity models, postcolonial theory "offers a broader cultural and historical scheme within which the Americanization of processes of management can be understood and analyzed." Clearly, both in the light of its long colonial history and its growing relevance for the Western world, the theory is especially applicable to India both at the country-level (see Khilnani, 1997; Dirks, 2001) and at the level of situated organizations (see Cohen \& El-Sawad, 2007; Mir \& Mir, 2009; Varman \& Saha, 2009). 
At this stage, we emphasize again that the term postcolonial theory should not be taken literally as a theory that looks into asymmetric relations only between Western European organizations (representing the original colonizers) and organizations in the developing world (representing the once colonized). Drawing on the work of the well-known postcolonial theorist Homi Bhabha and articulating the core principles of postcolonial theory, Frenkel $(2008$, p.925) points out that the "post" in postcolonial theory "does not designate a time after colonialism or those social and political phenomena that are seen to be its direct consequences. Rather it refers to the assumptions behind the ideological discourses of colonialism". From an organizational perspective, then, postcolonial theory is conceptualized and deployed as a theory which deals with key aspects of 'colonial style' asymmetrical power relations that govern modern organizations. Additionally, the theory asserts that more often than not such asymmetrical power relations have a strong historical basis linked to imperialistic ambitions, cultural stereotyping, prejudices and a cognitive disdain for the notional 'other' (see Said, 1978; Jack et al., 2011; McKenna 2011). Thus, scholars have often used postcolonial theory more generally, to understand for example, the structure of engagement between a large powerful American firm and a relatively less well-known firm in the developing world, which on paper operates freely in globalized markets, but in reality depends almost entirely on American institutional policies for its survival.

\section{Various strands of Postcolonial theory}

Given the contentious nature of the issues the theory raises, it is perhaps to be expected that there are different versions or strands of postcolonial theory. Generally speaking, these versions can be classified into three dominant schools of thought (OzkazancPan, 2008), although they are not mutually exclusive. The first school, building on Foucault's (1972) discourse analysis, has looked at how representations of the Eastern world are underpinned by designs of creating and maintaining asymmetric power and control relations that favour the Western world (Goss, 1996; Kapoor, 2002). In modern history, there is plenty of evidence of such asymmetric relations. For instance, "if we consider control rather than actual occupation of territory, by the early decades of the twentieth century a handful of Western countries directly or indirectly controlled about ninety percent of the globe" (Prasad, 2003, p.4). Loomba (1998) points out that by the 1930s colonies and ex-colonies of Europe covered about eighty-five percent of the world and that colonialism drove a massive restructuring of non-capitalist economies in order to fuel European capitalism. The first school of postcolonial theory thus emphasises a deliberate and one-sided manipulative intent 
on the part of Western colonial powers, an exemplar being Edward Said's (1978) highly influential book Orientalism.

The second school of postcolonial theorists have drawn mainly on Antonio Gramsci's (1971) notion of the 'subaltern' (i.e. those people or classes of people that are seen as inferior in status or rank) to deconstruct the structure and workings of asymmetric power relations between groups. This school of postcolonial thought is popularly referred to as the Subaltern studies group (see Guha, 1989). It points out that subaltern groups in the world have no voice and that everything we know about such groups is via the distorted representations produced by the elite and powerful groups, a process which ensures the sustenance and continuity of the existing asymmetries of power (Spivak, 1988; Ozkazanc-Pan, 2008). While the first school of postcolonial thought offers a broad, overarching critique of global asymmetric power relations, subaltern studies considers the position of specific subaltern groups in relation to such asymmetries. For instance, Gayathri Spivak, one of the most cited subaltern studies' scholars, provides a trenchant analysis of the peripheral position of women in postcolonial India. She argues that women are doubly disadvantaged: they are outside the scope of Western feminist theories of emancipation and are also marginalized by internal power asymmetries within the country (see Spivak, 1988, 1999).

A third school of postcolonial thought argues that asymmetric relationships of power rather than being one-dimensional and one-sided as suggested by Said (1978), are inherently complex (Bhabha, 1994; Frenkel, 2008; Ozkazanc-Pan, 2008). In his work The Location of Culture, Bhabha (1994) argues that cultural values, norms and practices, which emerged during the colonial encounter and its aftermath, are not homogeneous and pure as explicitly projected in the literature. There is in fact a complex hybrid at play resulting from the "mixing of practices between colonizers and the colonized...a translation of texts and practices from the colonies to the metropole, and vice-versa" (Frenkel \& Shenhav, 2006, p.856). One major implication of Bhabha's work is that organizations and individuals in postcolonial settings can be seen to operate in increasingly inter-linked and heterogeneous hybrid environments. Such a hybridization process may make it possible for managers to navigate through a number of sophisticated cultural repertoires and resources and to demonstrate their agency, even when power asymmetries dominate (Frenkel, 2008; Ozkazanc-Pan, 2008). Thus, hybridization suggests that while the postcolonial order and the associated power relations may compel managers to unconsciously 'mimic' the West, such mimicry need not imply a complete cognitive surrender (Bhabha, 1994; Frenkel, 2008). 
Organizations draw on a number of hybrid cultural possibilities and successfully pursue their strategic interests. As Ashcroft (2001, p2) observes, "a common view of colonization which represents it as an unmitigated cultural disaster, disregards the often quite extraordinary ways in which colonial societies engaged in and utilized imperial culture for their own purposes." In this third version, therefore, postcolonial theory becomes an important device for analyzing the cultural dynamics of not only power, but also of adaptability, resilience and resistance in the process of colonialism and its purported aftermath (Kwek, 2003). It is this third school of thought that we adopt in this paper.

We suggest that some of the ideas within this school of thought bear relevance to the Indian IT offshoring sector. The spectacular growth of Indian offshoring organizations amidst reports of uneasy relationships and cultural tensions with the wider Western world (see Lacity \& Rudramuniyaiah, 2009; Upadhya, 2009; D’Mello \& Eriksen, 2010) lends credence to this third version of postcolonial theory. It also turns our attention to the asymmetric elements of power in play within the social life of vendor organizations and to the processes through which managers might negotiate them. We draw on some key concepts from this version of the theory such as agency, identity and mimicry, to help understand and explain our findings. Table 1 below is a summary of the important concepts employed by postcolonial theory in general and by this strand of the theory in particular.

Table 1. Definitions of terms used in postcolonial theory

\begin{tabular}{|c|c|}
\hline Term & Definition \\
\hline Agency & $\begin{array}{c}\text { The capability of groups to independently and purposively further their } \\
\text { interests within the postcolonial context (see Ashcroft, 2001; Kwek, 2003). }\end{array}$ \\
\hline Mimicry & $\begin{array}{r}\text { Copying of the cultural practices of powerful high status groups by the less } \\
\text { powerful, low status groups. It is often done unconsciously without thinking } \\
\text { (see Bhabha, 1994). }\end{array}$ \\
\hline Hybridity & $\begin{array}{r}\text { The mixing, blending and intermingling of practices, values and norms and the } \\
\text { resultant cultural forms (see Bhabha, 1994; Frenkel, 2008). }\end{array}$ \\
\hline Identity & $\begin{array}{r}\text { The sense of self of people within groups. These groups are locked into an } \\
\text { asymmetric, colonial-style relationship with other groups (see Cohen \& El- } \\
\text { Sawad, 2007). }\end{array}$ \\
\hline Adaptability & $\begin{array}{c}\text { The ability of groups in postcolonial contexts to effectively adapt to unequal } \\
\text { power relations (see Kwek, 2003). }\end{array}$ \\
\hline
\end{tabular}




\begin{tabular}{|c|c|}
\hline Resilience & $\begin{array}{r}\text { The ability of groups to absorb the conflicts created by power asymmetries and } \\
\text { to strategically reorganize in response (see Ashcroft, 2001). }\end{array}$ \\
\hline Resistance & $\begin{array}{r}\text { Strategic acts of subtle rebellion against power asymmetries (see Frenkel, } \\
2008 ; \text { Prasad \& Prasad, 2003). }\end{array}$ \\
\hline
\end{tabular}

\section{IT offshoring and postcolonial theory}

The IS research literature on IT offshoring has tended to examine issues from one of three perspectives: (1) the client's perspective (2) the management of the client-vendor relationship (3) the vendor's perspective. The first and the most common perspective focuses on the benefits and costs of offshoring for client organizations in the West. Here, researchers have typically drawn on theories such as Transaction Cost Analysis (Grover, et al., 1996; Lacity \& Willcocks, 2001; Hirschheim, et al., 2002; Dibbern et al., 2008) or the Resource Based View of the firm (Saunders, et al., 1997; Hahn et al., 2009). Some researchers within the client perspective have also used theoretical lenses which emphasize the socio-cultural side of IT offshoring (e.g., Levina \& Vaast, 2008). Generally speaking, most of the studies within the client perspective have shown that the promise of lower costs is one of the key reasons given for IT offshoring (Earl, 1996; DiRomualdo \& Gurbaxani, 1998; Bardhan et al., 2006; Dibbern et al., 2008). The second perspective has focused on the management of the client-vendor relationship (e.g., Avison \& Banks, 2008; Mehta \& Mehta, 2009; Willcocks \& Griffiths, 2010). The main concern of these studies has been the effective management of the processes and mechanisms which contribute significantly to the realization of a mutually beneficial relationship. The third perspective, which is the perspective we adopt in this paper, has looked at IT offshoring from the point of view of vendor organizations and their employees in offshore locations (eg., Heeks, 1999, D'Mello \& Eriksen, 2010). Within this perspective, researchers have focused on issues such as vendor organizations' choice of contracts with their clients (Gopal, et al., 2003), processes of controlling offshoring projects (Levina \& Ross, 2003) and the management of cultural issues within IT vendors (Ravishankar et al., 2011).

\section{The notion of power in IT offshoring research}

Within the extensive body of research on IT offshoring, we can identify three distinct conceptualizations of 'power'. First, power-related attitudes are shown to be entrenched in national cultures, thereby directly affecting vendor-client collaboration and coordination efforts. Such a view of power is best mirrored in the 'power-distance' scores given to 
countries (Hofstede, 1980), which managers involved in IT offshoring relationships are often asked to take into account when negotiating and interacting with their client (and vendor) counterparts (see Jain et al., 2011; Levina \& Vaast, 2008). Power, then, is considered to be something which exists outside the IT offshoring arrangement as a particular cultural orientation of nation states (see Beulen \& Ribbers, 2003). Second, power is described in terms of establishing strict control over the various collaborative processes involving vendor and client teams. In this view, power can be completely written into and entirely managed through contractual specifications, obligations and service-level agreements between vendor and client organizations (see Aron et al., 2005; Goo et al., 2009). A third conceptualization of power in IT offshoring research puts forth arguments about the dwindling regulatory powers and authority of nation states and the corresponding rise of powerful global MNCs, which are seen as important drivers of the IT offshoring phenomenon (see Bunyaratavej et al., 2011). From a vendor perspective, we acknowledge the usefulness of these conceptualizations of power. But we argue that there is much to be gained by making the vendor perspective broader still by examining it through a postcolonial lens. Postcolonial theory draws our attention to the wider contexts of the IT offshoring phenomenon. It helps us to see how micro-level activities in a vendor organization are embedded within the wider context of postcolonial power relations and also influenced by that context. As D'Mello and Eriksen (2010) have suggested, the dynamics of macro-level global events are often intricately intertwined with initiatives at the organizational level.

\section{Framing a postcolonial interrogation of IT offshoring vendor organizations}

Two clusters of initiatives, which form a core part of the essential strategic and social infrastructure of IT offshoring vendor organizations, are particularly amenable to postcolonial analysis (it should be noted that we conceptualized these two clusters based on our preliminary analysis of the data). Within the first cluster, we may consider the wide range of management models and practices imported primarily from American business organizations in order to establish effective control over various organizational units and resources (Frenkel \& Shenhav, 2003; Upadhya, 2009). For instance, initiatives promoting strong corporate cultures and best practices such as knowledge management, quality management, training programs, metrics driven project management and so forth are showcased as mechanisms which provide greater control over projects and human resources (Oshri et al., 2007; D’Mello \& Eriksen, 2010; Ravishankar et al., 2011). In the IS literature on offshoring vendors, such initiatives are usually seen as strategic imperatives crucial to meeting business objectives. In 
addition to the above views, a postcolonial analysis can be deployed as way of developing insights into the historical hierarchies of power underpinning such initiatives (Ashcroft, 2001; Prasad, 2003). The main thrust of a postcolonial lens in this instance would be to consider the relationship between strategic internal initiatives and vendor organizations' experiences of power differences. A postcolonial analysis has the potential to empirically examine to what extent such a cluster of initiatives reproduce global asymmetric power relations and the degree to which vendors are coerced to overlook indigenous models and practices in favour of Western ones (Frenkel \& Shenhav, 2003; Frenkel, 2008). On the other hand, in the light of the hybrid business environments of today's globalized world, a postcolonial analysis of the cluster can also throw light on the agency of the vendors and help us assess the degree to which vendors' mobilization of strategies of adaptation and change are conscious responses to postcolonial power relations (Ashcroft, 2001).

The second cluster of initiatives encompasses processes of organizational identification management. The IT offshoring literature suggests that employees in vendor organizations are coaxed to develop multiple organizational identifications and consequently possess the ability to switch between their different identities with great ease. For instance, Ravishankar and Pan (2008) show how managers' nurturing of multiple identities in an Indian IT vendor organization led to employees identifying closely with two organizations, namely the Western client organization and their own organization. These dual identifications were deliberately orchestrated as part of organizational strategy and provided a distinct competitive advantage to the Indian vendor. Also, in the context of offshoring of business processes, research has shown how employees are trained to transit seamlessly between their Indian identity and the American identity when interacting with customers (McMillin, 2006; Das et al., 2008). In the IS literature, considerations of organizational identification and identity in the offshoring context are usually described in strategic terms and in relation to their key contribution to effective customer relationship management (e.g., Ravishankar \& Pan, 2008). However, we would suggest that there are particularly important aspects here that are highlighted with a postcolonial point of view. A postcolonial approach to identity processes in vendor organizations helps us explore the management of multiple identities not only as innocent aspects of customer relationship management, but also as key elements in a larger array of conscious responses to perceived power asymmetries (Bhabha, 1994). A postcolonial reading of identity in vendor organizations may also be employed to examine the ability (or lack of) of offshoring vendors to make sensitive cultural adjustments and how such 
adjustments may relate to their experiences of power differentials. Further, a postcolonial approach to identity may be used to pose a legitimate challenge to binary and essentialist notions (McMillin, 2006; Frenkel, 2008) of organizational and national identities (and cultures), which have tended to dominate IS offshoring research.

In summary, our review of the IT offshoring literature on vendor perspectives highlights an important analytical and practical void. Most previous IS research has looked at vendors' relationship with their client organizations as a globalization-led strategic arrangement whose antecedents and consequences can be contained and managed completely within the conventional system of frameworks available in the literature. While these frameworks and associated empirical findings are valuable, we suggest that the much broader lens of postcolonial theory can be fruitfully used to empirically examine how IT offshoring vendors experience and respond to asymmetrical power relations. A key point of this paper is that the IT offshoring phenomenon is embedded within a much larger context, this larger context being that of globalization and postcolonialism (see Lunga, 2008). We believe that a postcolonial approach adds a novel and useful dimension to extant IS offshoring research and also contributes to a fuller understanding of the IT offshoring phenomenon.

\section{Research Method}

In this study we aimed to examine how Indian IT offshoring vendor organizations experience and respond to power asymmetries in their relationship with client organizations. To do this we adopted the interpretive ethnography research method (Myers, 1997a; Klein \& Myers, 1999; Myers, 1999). Interpretive researchers assume that access to reality (given or socially constructed) is only through social constructions such as language, consciousness and shared meanings (Walsham, 1995a, 1995b; Myers, 1997). From the interpretive perspective, "the same physical artifact, the same institution, or the same human action, can have different meanings for different human subjects, as well as for the observing social scientist" (Lee, 1991, p. 347). However, given our emphasis on postcolonial theory, our study leans more towards "critical interpretivism" than the more traditional forms of interpretivism (Doolin \& McLeod, 2005). Unlike traditional interpretivistic approaches, critical interpretivism is explicitly concerned with how particular interpretations of organizational reality are connected to wider historical contexts and considerations of power structures (Alvesson \& Deetz, 2000; Myers and Klein, 2011). Grounded in anthropological and sociological traditions, the interpretive ethnographic method is helpful for revealing the ways 
in which employees in specific work arrangements come to understand and manage the subjective realities of their everyday situations (Van Maanen, 1979; Geertz, 2000). We conducted our ethnographic fieldwork at Indshore, a large Indian IT offshoring vendor organization.

\section{Research site}

Indshore serves more than 200 global clients, has more than 35 software development centres and sales offices world-wide, and employs more than 25,000 people. North American and European clients contribute to about ninety-percent of the organization's revenues. Indshore offers IT offshoring and consulting services to clients in a diverse range of industry segments including manufacturing, retail, financial services, health care and telecommunications. Indshore saw rapid growth in the late 1990s and early 2000s, a period during which it graduated from short-term, one-off projects to handling more complex software development, maintenance, testing and package implementation projects. It operates software development centres in several large Indian cities and is prominently showcased and praised in the business media for its successes. Four years prior to the start of our fieldwork, Indshore was certified to be at level five of the Capability Maturity Model (CMM) for software development, an achievement carrying much weight within the global IT offshoring environment and commonly interpreted as a 'top-quality' benchmark for vendor organizations.

\section{Access and data collection}

In the first instance, access to Indshore was negotiated through a middle-level manager. Subsequently a member of Indshore's senior management team agreed to support an initial period of fieldwork involving semi-structured interviews at one of Indshore's offshore software development centres. Following this initial investigation we obtained the support of the senior management team for a wide-ranging ethnographic study of Indshore's experiences of managing relationships with their Western clients.

Table 2. Interviews and Role of Interviewees

\begin{tabular}{|c|c|c|}
\hline Group & Role of Interviewees & No of interviews \\
\hline 1 & Project-team members & 13 \\
\hline 2 & Middle-level managers & 35 \\
\hline 3 & Senior managers & 12 \\
\hline
\end{tabular}


The first author conducted intensive fieldwork at Indshore for eight months. He attended a number of internal meetings of project teams where employees discussed several problematic aspects of their client relationships. Hundreds of pages of field notes were produced in this process. The field notes were also generated by 'hanging around' in the cafeteria areas and interacting informally with employees. When employees were told about the objectives of our study, free-wheeling discussions often ensued, which provided some serendipitous inputs into our study.

In addition to the intensive fieldwork, much of the data was generated by 60 in-depth interviews with informants in seven business units. Table 2 summarizes these interviews by grouping the interviewees into three basic categories: project-team members (less than seven years of experience), middle-level managers (between seven and 15 years of experience), and senior managers (more than 15 years of experience). Interviewees spoke at length about their experiences of interacting with Western client organizations. They also extensively discussed the various strategies adopted by Indshore to develop their internal capabilities and to manage sensitive issues in their engagement with clients. 32 of the 60 interviews were audio-recorded and transcribed. Detailed notes were made on the remaining interviews immediately upon their conclusion.

\section{Data analysis}

We approached our ethnographic fieldwork with a broad aim to explore Indshore's experiences and responses to asymmetries of power in their relationship with Western client organizations. After our eight month period of fieldwork, we had collected vast amounts of primary and secondary data. We analyzed our empirical material in three steps. Firstly, we carefully re-read all the interview transcripts and field notes with a view to identifying issues of power relations with clients. Given the critical ethnographic orientation of our study, we anchored our analysis in two overarching sets of thick narrative descriptions, which underscored and exemplified informants' numerous experiences of asymmetrical power relations with client organizations: the first set of thick descriptions pertained to the implementation of the knowledge management project (KMP) and the second drew on the performative aspects of the conduct informants staged for their clients. Permeating both sets of narratives were informants' perceptions of imbalances in power relations and their beliefs about how they were coping with it. Secondly, we analyzed the linkages between the thick 
narrative descriptions and the extant conceptualizations of power asymmetries within the postcolonial literature. These linkages helped us to develop our theoretical insights. Thirdly, we formally presented our findings and our insights to the senior management team at Indshore during an internal seminar. The feedback from this process helped us to write our analysis of the Indshore case presented below.

\section{An analysis of the Indshore case}

We will now present an analysis of the Indshore case. As noted above, our analysis builds on two sets of rich narratives about power asymmetries, which permeated our fieldwork: in the first, we present a critical evaluation of the implementation of the knowledge management project (KMP) and in the second, we examine the staged performances of dis-identification by Indshore employees. We begin our analysis with an edited excerpt from our field notes.

Location: Indshore cafeteria: Kiran turns back every few moments in the hope of locating an empty table in the food court. He is in a queue leading to the counter at the pizza joint. A few minutes later he finds a table at the far end of the food court. He is soon joined by Vikas who congratulates him on managing to find a 'nice spot' for lunch. Kiran and Vikas were classmates during their undergraduate engineering degree days and ten years later are employed as project managers at Indshore. Vikas asks Kiran if he had read the newspapers that morning. Very soon, over lunch they are discussing the views of a local political leader which has appeared in all the leading newspapers. This leader has complained that while IT offshoring organizations were given land at throwaway prices by the local state government, these organizations had failed to fulfil their responsibilities to the state and had done precious little by way of reserving jobs for the local population. Vikas shakes his head slowly and says: "Of course the state government has supported us to an extent, of course the city's infrastructure is bad, but we in the IT industry are doing our best for the state and city. As far as preferential treatment in IT jobs goes, forget it. These politicians have no clue about the pressures we face; we just need to pick the best man for the job, as it is the Americans think we are backward. ..."

Kiran thinks hard for a few seconds: “It really doesn't matter what the local politicians say. The basic thing is that local issues do not affect us as much as international ones. If you simply look at the number of jobs created by the IT industry here and the dollar value of software exports from here, it is massive. So the government can't afford to create 
any trouble for us. Of course, we deal with local issues everyday - the drive to work is really dangerous . . . potholed roads, frequent power cuts and everything . . but in reality, more than all these issues, we are directly affected by the sentiments in the US. "

Kiran is distracted by a loud group at the next table who are discussing the special effects in a recently released animated movie. He is annoyed: "Freshers, joined just last week, are going through induction training now." Kiran now has to speak louder to get his point across because there is a buzz in the food court, generated by the large crowd: "A few states in the US will be soon introducing anti-offshoring bills that plan to restrict companies registered in these states from offshoring jobs. Now this is something that is really worrying and frankly we can do nothing about it except issue statements in the media like 'It's actually US that is benefiting from offshoring' . . we have to constantly watch out in this business. And you have to listen to some of the talk coming out of the US!! Someone said Indian companies are chopshops. I mean how prejudiced can you get."

Vikas chips in: "Ya, I see what you mean. If any government here in India dares to tell us that we have to prefer only local residents and so on, we can just say, 'nothing doing', but it's more touchy when the US starts talking about 'stopping offshoring' or 'protecting US labor interests', we can't just shrug our shoulders and ignore it. They have the power and they have all these stereotypes about India . . I mean it's not just about free markets alone. The bottom line is we rely on US capital and in our business they call the shots. So we just have to hope for the best." Now, Kiran waves at someone who is talking into his mobile phone and at the same time writing furiously on a scribbling pad. He is Jay, a senior software engineer. Kiran says by way of introduction: "Jay is very very talented and is into all kinds of politics, local, national and international (laughs). He surely has an opinion on this one."

Jay puts down his mobile phone on the table and after the others have explained the topic of conversation, he speaks softly. "The challenge for Indian IT companies now is to move up the value chain. There is a perception, even amongst some of us here, that we are only doing routine jobs like maintenance. So as our CEO always says, the only way out is to move up the value chain and do things that are really high end. Then it will be fun. Then the balance will shift towards Indian companies. But this is only one side of the story. Whether we get projects or not in the future may not be always determined by logical factors like cost savings for clients. I mean I am kind of worried that despite globalization and everything, 
many Americans still believe India is backward and untrustworthy. I think until we have a strong demand from within India, we will never have a level playing field. ”

\section{Organization-wide initiatives at Indshore: The knowledge management project}

For senior managers at Indshore 'moving up the value chain' was synonymous with the capability to anticipate and create innovative technology solutions in a very competitive and increasingly price-conscious business environment. To spur innovation within the organization, Indshore had recently launched a number of what managers described as 'corporate best practices' or 'organization-wide initiatives'. From a strategic perspective, such practices were seen as part of the structural interventions necessary to spearhead creativity and imagination within the various organizational business units. One organizationwide initiative which all managers we interviewed spoke fondly about was the 'knowledge management project' (KMP). The KMP was an internally developed IT-based system, which consisted of different web-based applications and interfaces including databases, newsgroups, discussion forums and repositories of re-usable software code. Indshore made it mandatory for all employees to share their project experiences and upload case studies, white papers and re-usable pieces of software code on to the web-based KMP. In other words, the KMP was a platform which helped business units to share knowledge and to learn from each other's 'war stories'. Each employee's contribution to the KMP was carefully monitored by their managers and the employees deemed to have made the most useful contributions were given small monetary rewards at the end of the financial year. According to a senior vice-president (VP) of one of the Indshore's business units:

"We view our KMP initiative as an important control mechanism. It is a part of our portfolio of corporate best practices, all of which we use to control different aspects of the company. The KMP helps us control and manage the effective creation and flows of knowledge within the organization."

Although the KMP was developed internally, many of the ideas underpinning the initiative and the IT-based system came from scanning recent articles in the American business press and practitioner journals. It was felt that despite the significant historical and cultural differences between Indian and American companies, knowledge management initiatives created and mastered by American companies were excellent role models which could be implemented in Indshore. Indshore's senior management had in fact acquired a reputation for adopting various American productivity models and management practices. As 
one of the members of the senior management team responsible for the KMP implementation noted:

"The US leads in effective control mechanisms. I know that there have been a number of recent corporate scandals in the US, but we also know that they come up with some very innovative models like KM. Such models really help us understand how to better control our strategies and operations. So we took the XX model, which we liked, and tweaked it slightly to suit our industry. Based on this model, we developed our KM system."

Many of the senior managers who took part in our study also observed that by making it mandatory for employees to contribute to the KMP, Indshore was getting the best out of each and every employee. In the words of a business unit head:

"The KMP is helping us prepare well for the future. I would like to think that they also help business units learn from one another and ultimately such learnings will translate into some kind of benefits for our present and future clients. I must admit that at this stage I cannot really quantify the benefits of the KMP, but it does give us a broad overview of what is happening in different parts of the organization. So from a control point of view it is priceless.”

While most informants agreed that the KMP was an effective intervention aimed at nurturing and developing Indshore's internal capabilities, they noted that initiatives such as the KMP were also geared to impress clients. A senior project manager observed:

"The benefits of telling our American and European clients that we manage and control knowledge through our sophisticated KMP are huge. Given that we are still perceived by many American and European companies as dirty sweatshops full of cyber coolies, showcasing projects like KMP gives our reputation and image a boost."

Driving this impression management effort was also a fear that non-adoption of management practices and control strategies seen as most appropriate in the mainstream Western business literature could seriously jeopardize Indshore's competitive position in the IT offshoring industry. A project team leader, who shared his views on the subject argued:

"I agree that the KMP is in some ways useful to us. But this is also a game we play for our clients and for the business press from America and Europe. We cannot afford to be seen as sloppy by our clients. Very soon we will be hearing stories in the media about how backward and untrustworthy Indian firms are. This is a vicious cycle. So we have mechanisms like the 
KMP, through which we try to control our clients' view of us. Clients are often impressed by the fact that we have a technically advanced KMP just like any other American IT company."

In the course of the interviews, our informants admitted that using familiar corporate initiatives to enhance their image in the eyes of the client was a practice not restricted to organizations in the IT offshoring industry alone. Indeed, most business organizations across industries sought to impress their clients with such tactics. However, as a senior software engineer reasoned, the case of Indshore and other Indian IT offshoring companies was different in a fundamental way:

"The difference is this. I feel we are always on the edge because of this whole power thing. Despite everything, when I interact with clients there is a perception that we are backward. I mean no one has told me this explicitly, but we can all sense that they view us as inferior. I suppose it is this whole colonial mentality. And because they are more powerful, they can at any time create trouble for us. So we have to suck up to them. But as the world becomes flatter and flatter all this will change."

Thus, although at first glance the KMP appeared to serve only one major purpose - to enhance Indshore's strategic capabilities through the creation and development of an organization-wide knowledge platform - on closer examination, it became evident that it was also used as a careful ploy by Indshore managers to appear more credible and legitimate to clients in the wake of the existing asymmetries of power. The symbolic value of the KMP and its relevance to wider issues of power was nicely captured in the following complaint by a technical architect:

"I find it irritating that they don't even seem to recognize us as a legitimate entity. We are CMM Level-5 for god's sake. But still we get to hear how superior the West is and how pathetic the East is. I mean the top-management in the client companies very often rave about how great India is. But the reality at the project collaboration level is different. We still are bullied around because we are considered backward. And there are always these threatening noises made about how we are taking American and European jobs. So yes, we have no option but to be extra respectful, but whenever we get a chance we draw their attention to our best practices like the KMP in the hope that they give us more credit."

A project manager closely involved with the KMP implementation reasoned: 
"No doubt, we borrowed the whole KMP idea and concept from the Western world. Strictly speaking, we cannot claim it to be an original idea. But you must understand that we did not simply replicate how it is used in America. We worked hard to figure how it can be adapted to our Indian context. We created our own local knowledge taxonomies. To evaluate our KMP's maturity levels, we even developed a home grown model, which is now much acclaimed internationally. Next, the reward systems attached to the KMP has a distinct Indian flavour to it. All in all, you must not think that we wanted to impress our clients and so just copied a Western notion of KM. We deserve more credit than that."

Thus, assertions by managers that they were putting in a great deal of effort to gain respect from the 'influential' West by showcasing the KMP were also balanced by arguments about the overall utility of the KMP and how it stood as a testimony to Indshore's innovative capabilities and agency:

"There were many experts who said we were only copying a Western KMP model. This was a bit depressing because such comments only served to create a larger impression that Indshore was a sub-standard entity. But still we kept going with the KMP innovations and it is now a good blend of a Western notion and an Indian-style interpretation of KM."

Another project manager reiterated that the KMP had deeper motives while serving as a useful tool for managing knowledge:

"We try and gain respect through the KMP. I call it 'sexing' it up to show them that we are on par. What we achieve out of our KMP is important, but it would be naïve to think of the KMP only as tool to develop our own internal capabilities"

\section{The performance of dis-identification by employees}

While the strategic deployment of initiatives such as the KMP provide insights into one type of organized collective response to asymmetric power relations, deliberately staged shows of 'dis-identification' and 'un-indianness' by many Indshore employees in their interactions with clients highlight a different approach to managing the power imbalances. A project manager explained:

"Our client organizations and their employees are a lot more familiar about India than they were in the past. But we don't take any chances. We ensure that we showcase ourselves as disassociated from the chaos that India is known for. Even our CEO has a slight American twang although he has never lived in America for any length of time! We all joke about it at times. But this is serious business. We have to make them feel comfortable about dealing with 
us and to do this, yes, we have to hide our Indshore identity, which is our Indian identity, a little bit."

Other informants suggested that 'hiding the Indian identity' or 'dis-identifying' with it was not something restricted to the senior management alone. Many pointed to the popular phenomenon of Indian employees wearing T-shirts with logos of client organizations inscribed on them as a way of demonstrating their loyalty to clients. A software engineer observed:

"I feel we go overboard because we know there are a lot of negative stereotypes about Indians. It takes a long time to explain it away. It is much easier to adopt practices they are familiar with and also sound like them a little bit. You know, picking up American phrases like 'cool' and using it a lot when we talk to them virtually or face-to-face. This does not mean I have become American or anything. But practically it makes more sense to act like we identify more with the US and less with India."

In the words of another senior software engineer:

"I am fully aware that I am imitating and mimicking them. It is not that I am so influenced and enamoured by American accents and values that I have unconsciously internalized them. I am fully conscious that I do all this because of the power equations, you know. But I am sure we will not have to do all this once things even out a bit."

To most informants, putting on an appearance of dis-identification or alienation from things seen as too Indian was a necessary part of improving their legitimacy and credibility in Western eyes. Indeed, the most interesting aspect of these carefully orchestrated performances of dis-identification seemed to be the implicit, and at times explicit belief that this was a way of managing some of the asymmetries of power embedded in the offshoring arrangements. A project manager candidly recounted her conversation with counterparts from the client organization:

"I talked about how corrupt our Indian politicians are. They like to hear such things. For a moment, I don't think their politicians are any less corrupt. But they expect to see such things in India and we give it to them. It is not wise to start a fight about their prejudices. It is easier to make them comfortable by making them feel that we are part of them. I make it very clear to them Indshore is not really an Indian but a global company."

According to a project team leader: 
“We do this 'we are not really Indian' drama not because we have some colonial hang-over. I mean they have a colonial hang-over, but not us. We are who we are. But in front of them we are forced to pretend that we are really like them because whether we like it or not, they are the superpower and we have to pay our respects if we want business".

\section{Discussion}

The empirical data presented above provides us with an alternative and deeper understanding of Indshore's experiences of offshoring. It also vividly documents the broader tensions which undergird the responses of senior managers and other employees to the apparent power differentials. Interestingly, in contrast to some empirical research which paints a dismal picture and argues that employees in Indian offshoring organizations are marginalized and exploited (e.g., Mir \& Mir, 2009; Upadhya, 2009), our data highlights the impressive resourcefulness and strategic capabilities of Indshore's personnel. Within the wider business literature the tremendous growth of offshoring firms in India has contributed significantly to the idea that the new wave of globalization has levelled the playing field for organizations, that the West-East asymmetries of power are a thing of the past, and that the 'world is now flat' (Friedman, 2005; Dossani \& Kenney, 2007, 2009; Nilekani, 2009). In our case, Indshore's KMP is a small but important example of how managers within the Indian IT offshoring environment are now able to easily access and scan the globe for corporate initiatives, to borrow Western models that fit their business strategies, and to refine these models and implement them as effective mechanisms of control within their own organizations (Upadhya, 2009). From a theoretical perspective, the KMP at Indshore resonates with postcolonial scholars' conceptualization of a 'hybrid' practice, which refers to a practice resulting from the historical and ongoing intermingling and blending of systems, organizational forms and management models belonging to different cultures and countries (Bhabha, 1994; Frenkel \& Shenhav, 2003; Frenkel, 2008). In fact, in explaining hybridization some scholars have specifically pointed to the improvised adaptations and modifications of American technology and management practices (e.g., Zeitlin, 2000). The parallels with the KMP are evident. The KMP at Indshore was neither a completely indigenous creation nor was it an exact replica of a Western management practice. Rather it emerged out of a mixing of ideas and practices developed in the US with the realities of Indshore's local operations in India. Put differently, the KMP was initiated as a hybrid of Indshore managers' experience of American models of $\mathrm{KM}$ and their largely Indian training and backgrounds. In hybrid practices such as the KMP, then, we see tangible evidence of the agency, adaptability and 
resilience (Ashcroft, 2001) of Indshore, and by extrapolation, of other similar vendor organizations that are often viewed in postcolonial literature as historically disadvantaged.

\section{Hybrid practices and power asymmetries}

Hybrid practices are further implicated in the carefully developed manoeuvres and responses of organizations to historically grounded imbalances of power (Bhabha, 1994; Loomba, 1998; Prasad \& Prasad, 2003). As evident from many parts of the empirical data, the confident implementation of a hybrid practice such as the KMP does not signal a complete absence or nullification of the asymmetrical power relations between Indshore and its Western clients (Gilroy, 1993; Frenkel \& Shenhav, 2003, 2006). Rather, they bring into sharp focus the experiences and responses of Indshore to the imminent dangers of unequal power arrangements underlying IT offshoring (see D'Mello \& Eriksen, 2010, p103). Of course, the concerns of Indshore are not reflected in any explicit threats or flamboyant displays of power and status on the part of Western clients. Rather, the undercurrents of power are manifest in more subtle ways, which we can begin to understand by carefully examining the implementation of initiatives like the KMP.

In analyzing the KMP, we can explain its deployment, alongside its more visible strategic business dimensions, as a conscious device geared to carefully manage the power asymmetries. Clearly, managers and employees at Indshore viewed the descriptions of Indian IT organizations as 'dirty sweatshops' and employees as 'cyber coolies' as grossly unfair and biased (see Ramesh, 2004; Cohen \& El-Sawad, 2007). By introducing the KMP, managers felt that they could impress their more powerful Western clients, gain legitimacy and preempt any similar stereotypical Western assertions in the future about Indshore. In their view, the adoption of practices familiar to Western organizations enhanced their image in the eyes of their Western clients. Such a boost was seen as essential, given the long-standing prejudices that their more powerful clients were believed to hold against Indian companies. Furthermore, our informants argued that the apprehensions of employees in Western client organizations and of the larger Western media were more fundamental and historical than those voiced by client organizations against their vendors in any typical business relationship. According to our informants, central to these fears and biases were stereotypical notions about the inherent backwardness and inexperience of Indian organizations (see Beulen \& Ribbers, 2003; Zaidman \& Brock, 2009) and somewhat paradoxically, the threat of losing 
jobs to a talented Indian workforce in today's globally interconnected business environments (see Cohen \& El-Sawad, 2007; Zimmermann \& Ravishankar, 2011).

One way of counteracting this apparently biased discourse was to imitate Western management models and practices. By doing so, managers believed they would gain the respect of their clients. These beliefs suggest that at a fundamental level the KMP can be seen as a strategic tool deployed by managers to change Indshore's image from that of an unfamiliar and culturally distant Indian vendor to a familiar, almost Western organization (Bhabha, 1994; Frenkel, 2008). While familiarity in this instance was evidenced by the KMP initiative, we would suggest that different corporate best-practices may play this role at different times within vendor organizations. One interesting observation coming out of the above discussion is that although the demand to implement the KMP was not explicitly made by the clients, the pressure to implement was implicitly felt by managers at Indshore. This gives us some indication of the deep levels at which dynamics of power operate. Of course, it is obvious that managers did not conceive and implement the KMP with the sole purpose of managing the power dynamics with the clients. They did believe that the KMP was a useful resource, which helped in the development of Indshore's strategic capabilities. This view of the KMP implementation as a capabilities development strategy finds solid support in IS strategy research (e.g., Oshri et al., 2007; Ravishankar et al., 2011). But the point we wish to highlight is that in addition to its typical IS strategy orientation, the KMP also had a significant symbolic dimension linked to Indshore managers' experiences of asymmetries of power (see Table 3).

\section{Power asymmetries and the performances of mimicry}

Our data further suggests that vendors' responses to unequal power arrangements do not find expression only in formal initiatives and best-practices such as the KMP. In the light of our fieldwork, employees' carefully staged presentations and performances for their clients, which are ordinarily framed in the literature as integral components of IT vendors' customer-centric doctrines (e.g., Levina \& Ross, 2003; Upadhya, 2009; D’Mello \& Eriksson, 2010) or in some cases as representative of organizational culture and identity (e.g., Ravishankar \& Pan, 2008) may also be understood as a carefully considered response to perceived power asymmetries. In their interactions with clients, our informants underplayed their Indian identity, staged deliberate shows of un-Indianness, and tried to sound and act like Americans. These successful performances of mimicry and imitation were professional 
presentations whose apparent purpose was to make the clients comfortable and to endorse the overall superiority of Western management practices and world-views (see Bhabha, 1994, p122; Ozkazanc-Pan, 2008, p968).

One remarkable aspect of Indshore employees' mimicry is not so much the act itself, but the reflexive awareness displayed by informants about their mimicking actions and the associated rationales and consequences. In other words, alongside the mimicry is a reflexive awareness of one's ascribed position within the offshoring environment and of the potential impact of mimicry on their relationships with clients. Here, our data supports and contributes to the postcolonial literature linking mimicry and power in crucial ways. The tendency of the notionally less powerful (Indshore) to mimic and imitate the practices and modes of conduct of the more powerful (Western- largely American - clients) can be seen as an important reminder of the unequal relations which govern postcolonial encounters (Frenkel \& Shenhav, 2003; Frenkel, 2008). But the strong reflexive protests of Indshore employees - that mimicry does not alter their identities - potentially challenges one of the key arguments of postscolonial theorists. Postcolonial theorists claim that the demands of mimicry fundamentally reconstitute the identities of the less powerful entity (Bhabha, 1994). Rather than viewing them as identity altering, however, Indshore employees considered mimicry and imitations as 'play', albeit one that had a deeper purpose. Also, while postcolonial literature argues that in making the unfamiliar familiar mimicry helps the powerful entity control the less powerful one (Bhabha, 1994), from Indshore's perspective we found mimicry to be a very creative approach to managing the offshoring relationship. Mimicry did not actually result in relinquishing any control to Western clients. Far from being duped, coerced or controlled, Indshore employees appeared to be acutely aware of the processes at work. They had made a conscious decision to participate in the mimicry as a response to what they saw as historically grounded power differentials.

In brief, the experiences and responses of employees to the perceived asymmetrical power relations serve to showcase simultaneously the agency of Indshore (Ashcroft, 2001) as well as its precariousness and vulnerability to postcolonial expressions of power (Mir \& Mir, 2009). In adapting a postcolonial framework we drew on a specific corporate best practice the KMP initiative - as well as on more general performances staged by Indshore employees for their clients. Theoretically, our informants' anxieties about effectively managing the power relations in their relationships with clients raise critical questions about the extent to which the world is really 'flat'. It also echoes recent nuanced observations by postcolonial 
theorists that power is deeper and more constructive than its typical conceptualizations as an empirically observable resource (Peltonen, 2006; Frenkel, 2008). By teasing out some of the less obvious and less explicit rationales for the KMP implementation, and by considering the reflexive shows of dis-identification by employees, we believe we have been able to generate some useful insights into some of the deeper dimensions of power asymmetries anchoring IT offshoring relationships. Table 3 provides a summary of the postcolonial interpretations of our data along with their more conventional conceptualizations in empirical IS offshoring research.

Table 3. Postcolonial interpretations of the Indshore data

\begin{tabular}{|c|c|c|}
\hline $\begin{array}{l}\text { Focal aspects of research } \\
\text { interest }\end{array}$ & $\begin{array}{l}\text { Conventional IS research } \\
\text { framings }\end{array}$ & $\begin{array}{l}\text { Postcolonial readings and } \\
\text { interpretations }\end{array}$ \\
\hline $\begin{array}{l}\text { Implementation of } \\
\text { organizational knowledge } \\
\text { management }(\mathrm{KM}) \\
\text { strategies. }\end{array}$ & $\begin{array}{l}\text {-Largely IS strategy } \\
\text { orientation: focuses on } \\
\text { development of core } \\
\text { competences and strategic } \\
\text { capabilities. } \\
\text {-Draws on the resource-based } \\
\text { view and knowledge-based } \\
\text { view of organizations. }\end{array}$ & $\begin{array}{l}\text {-Organization-wide initiatives } \\
\text { and corporate best-practices as } \\
\text { impression management } \\
\text { strategies. } \\
\text { - Demonstrates the agency of } \\
\text { organizations, but at the same } \\
\text { time underscores power } \\
\text { differentials. } \\
\text {-Can be understood as a hybrid } \\
\text { practice. }\end{array}$ \\
\hline $\begin{array}{l}\text { Processes of } \\
\text { organizational identity and } \\
\text { identification. }\end{array}$ & $\begin{array}{l}\text {-Strong emphasis on customer } \\
\text { relationship management. } \\
\text {-Creation and development of } \\
\text { strong corporate cultures and } \\
\text { identities. }\end{array}$ & $\begin{array}{l}\text {-Performances of dis- } \\
\text { identification staged through } \\
\text { deliberate acts of mimicry and } \\
\text { imitation. } \\
\text {-Can be understood as a way } \\
\text { of managing power } \\
\text { differentials. }\end{array}$ \\
\hline
\end{tabular}

\section{Conclusion}

In this paper we have suggested that the IT offshoring phenomenon is embedded within the context of the longstanding imbalances of power in the relationship between the West and the East. Although the IS research literature has focused on various aspects of IT offshoring, the implications of perceived asymmetrical power relationships have been largely 
ignored by IS scholars. Hence, we have made an effort to address this gap by using concepts from postcolonial theory to understand and explain the experiences and responses of one Indian vendor. We believe that postcolonial readings and interpretations of IT offshoring add an important new dimension to previous IS research. We discuss some of the theoretical and practical implications of our paper below.

Firstly, our study of Indshore suggests that IS research needs to expand its corpus of basic frameworks for studying and explaining offshoring at the organizational level. Such an expansion will help accommodate the long-standing roles played by macro-level historical and institutional factors in shaping the strategic moves of IT offshoring vendors. With a broader arsenal of lenses, we may also be able to overcome some of the blind spots created when viewing the narrow business dimensions of offshoring as self-contained and complete units of analyses. The critical, macro-level perspective we have adopted draws attention to asymmetric power relationships between the vendor and client. On a related note, we would like to point out that the use of an unconventional theory (for IS research) such as postcolonial theory does not really challenge existing perspectives in IS offshoring research; rather it adds a novel dimension to our understanding of offshoring relationships. We therefore suggest that IS researchers (particularly scholars who approach IT offshoring research from a vendor perspective) should develop a general awareness of this dimension i.e. a general 'postcolonial sensibility'.

Secondly, our paper shows how power in the context of vendor-client IT offshoring relationships is not something to be understood as a construct external to vendors' corporatebest practices or customer-focused initiatives. On the contrary, asymmetric power relations appear to be deeply embedded and implicated in the very process of creation and development of practices within vendor organizations. As a corollary to this theoretical implication, we would argue that empirical IS research needs to avoid simplistic and mechanistic formulations of power in studies of offshoring.

Thirdly, our study shows how power asymmetries are not easily visible as overt demonstrations of force or status by client organizations. Instead, they exist at deep levels and can be discovered only through in-depth assessments of the agendas underpinning different initiatives in vendor organizations. An important responsibility, therefore, rests on the shoulders of qualitative IS researchers, who are particularly well-placed to decode the contextual meanings of organizational practices and everyday talk. 
Fourthly, our study contributes to postcolonial theory by demonstrating how asymmetrical contexts of power cannot be ignored when examining hybrid practices (Shimoni, 2006; Frenkel, 2008). There is a growing tendency to present hybrid practices as conclusive evidence of a 'flat world' in which power asymmetries deserve little attention since they are deemed to have almost disappeared (see Friedman, 2005). In this paper, we have provided empirical evidence of how hybrid practices and asymmetric power relations are by no means mutually exclusive conditions (Frenkel and Shenhav, 2006). Rather, they can be understood in concert as two sides of the same coin. Scholars therefore need to avoid falling into the trap of ignoring unequal power relations when examining hybrid practices in organizations.

Fifthly, the ability of Indshore employees to skilfully engage with multiple cultural imperatives indicates that globally-focused modern IT offshoring organizations rarely produce cultural stereotypes amenable to lodgement into simple formulations of national/organizational cultures and identities. This reinforces the problems of attempting to understand organizational strategies and actions through narrow categorizations. As Frenkel (2008, p.939) argues, employing essentialist categories of nation and culture in empirical work on globalized contexts is now "less relevant as the various actors in the organization are increasingly exposed to a wide range of repertories, both through the electronic and the digital media, and as part of the increasingly frequent movement of people between different parts of the world."

Lastly, practitioners may find the empirical material in our paper useful in the process of better managing their own relationships with client organizations. While we admit that the specific circumstances of no two vendor organizations are exactly the same, the candid reflections of Indshore managers and employees may provide managers with a clear sense of the different ways in which asymmetrical relations operate and may suggest possible responses in non-confrontational and creative ways. Our study may also be used by experienced managers in vendor organizations to explain to new employees some of the logic behind the exaggerated deferential stance adopted in interactions with clients. Our study also has some relevance to offshore subsidiary units of multi-national organizations, given the cultural similarities. Even when they do not deal with a client from the West, subsidiary units are often locked in asymmetric power relations with the Western head-quarters (HQ). Managers in offshore subsidiary units may draw interesting parallels between Indshore's case 
and their own experiences. Such an analysis could help managers devise improvements in their relationship with the HQ.

We acknowledge four main limitations of our in-depth study. First, we studied one large Indian IT company only. While we have generalized from a single case to theory, the extent to which the Indshore case can be generalized to other settings will obviously vary (Walsham 1995b). The degree of power imbalances in vendor-client relationships will depend to an extent on the image and reputation of the vendor. Indeed, some well-known Indian vendor organizations have set-up subsidiary companies in the US and Europe, and are trying hard to build their global credentials. Whether such companies are experiencing postcolonial anxieties is a moot point. Further, vendor organizations are of different sizes and at different levels of maturity when it comes to delivering IT services from offshore locations. This leads us back to the question: Are Indshore's experiences with client organizations representative of a large number of vendor-client offshoring relationships in India? Clearly, our postcolonial perspective may not be so relevant in all situations. We recognize that its all Indian senior-management team and early reputation as a cheap, low cost Indian 'body shopping' unit could have made Indshore more susceptible to postcolonial asymmetries. Further, some aspects of globalization have made it much harder now to attach homogeneous national identities to vendor organizations and subject them to postcolonial analysis. The emergence of Indian offshore subsidiaries of American MNCs is a case in point. Despite these important qualifications, we would like to point out that Indshore is a highly regarded vendor in the global business community and that its history, organizational structure and service offerings are typical of many other India-based vendors. Hence, we suggest that our findings may be relevant to IT offshoring vendors in India and other developing countries.

Some recent offshoring research resonates well with our findings. Zimmermann and Ravishankar (2011) found that employees of an Indian IT subsidiary of a German MNC encountered a range of postcolonial asymmetries of power and status in their relationship with the German HQ and responded by reorienting and refining their professional role identities. In the case of the IT-enabled offshoring sector, studies adopting a postcolonial analytical frame have shown that historically embedded power asymmetries are integral to offshoring arrangements. They also vividly document the struggles of Indian employees in coping and coming to terms with their patently lower status (Cohen \& El-Sawad, 2007; Poster, 2007). 
The second limitation of our study is that, just like the typical IT offshoring lenses to which it provides an alternative, our postcolonial framework also runs the risk, at times, of offering mechanical and ready-made explanations for all experiences and practices of vendors. When offering postcolonial interpretations of IT offshoring, we certainly need to admit and recognize that unequal power relations underpin almost any relationship between a well-established, reputed client and a relatively less well-known vendor. Therefore, postcolonial approaches, if applied simplistically, are structurally subject to the same vulnerabilities that other more typical and mainstream analytical frames face. However, what we have done through our measured application of a postcolonial lens to Indshore's experiences is to show how the postcolonial context further amplifies existing power imbalances and adds a layer of complexity and uncertainty for IT offshoring vendors. Third, in our study we did not speak to any of Indshore's client organizations. While this is consistent with our focus on the vendor perspective, clients' perception of Indshore may provide useful counterpoints to our findings. Lastly, our theoretical lens may not explain the dynamics of power when smaller Western clients are in an IT offshoring relationship with large vendor firms in India. This is an increasingly prevalent phenomenon and the power relations in such cases may or may not lend themselves to postcolonial scrutiny. Further research is needed to explore such relationships.

We would like to suggest two other possible opportunities for further research. First, research could extend our study to IT outsourcing vendor organizations in the West and consider similarities and differences in patterns of power relations, with a possible emphasis on neo-colonial (rather than postcolonial) encounters with client organizations (Mir \& Mir, 2009). Second, research could also explore patterns of intra-organizational variations in how employees view strategic initiatives. For instance, empirical work could examine whether and why a group of middle managers may be cognitively predisposed to frame a strategic initiative as impression management in contrast to senior managers who may be more inclined to frame the same initiative as a capability development exercise (see Huy, 2011). 


\section{References}

ALVESSON M and DEETZ S (2000) Doing Critical Management Research. London, Sage.

APTE UM and MASON RO (1995) Global Disaggregation of Information-intensive Services. Management Science 41(7), 1250-1263.

ARON R, CLEMONS EK and REDDI S (2005) Just Right Outsourcing: Understanding and Managing Risk. Journal of Management Information Systems 22(2), 37-55.

ASHCROFT B (2001) Post-Colonial Transformation. Routledge, London.

AVISON DD and BANKS PP (2008) Cross-cultural (mis)communication in IS offshoring: understanding through conversation analysis. Journal of Information Technology 23(4), 249268.

BARDHAN I, WHITAKER J and MITHAS S (2006) Information Technology, Production Process Outsourcing, and Manufacturing Plant Performance. Journal of Management Information Systems 23(2), 13-40.

BEULEN E and RIBBERS P (2003) International Examples of Large-Scale Systems Theory and Practice II: A Case Study of Managing IT Outsourcing Partnerships in Asia. Communications of AIS 11(1), 357-376.

BHABHA HK (1994) The Location of Culture. Routledge, New York.

BUNYARATAVEJ K, DOH J, HAHN ED, LEWIN AY and MASSINI S (2011) Conceptual Issues in Services Offshoring Research: A Multidisciplinary Review. Group \& Organization Management 36(1), 70-102.

COHEN L and EL-SAWAD A (2007) Lived experiences of offshoring: An examination of UK and Indian financial service employees' accounts of themselves and one another. Human Relations 60(8), 1235-1262.

CONTRACTOR FJ, KUMAR V, KUNDU SK and PEDERSEN T (2010) Reconceptualizing the Firm in a World of Outsourcing and Offshoring: The Organizational and Geographical Relocation of High-Value Company Functions. Journal of Management Studies 47(8), 1417 1433.

D'MELLO, M. (2005) "Thinking Local, Acting Global": Issues of Identity and Related Tensions in Global Software Organizations in India. The Electronic Journal on Information Systems in Developing Countries 22(2), 1-20.

D'MELLO M and SAHAY S (2007) "I am kind of a nomad where I have to go places and places"... Understanding mobility, place and identity in global software work from India. Information \& Organization 17(3), 162-192. 
D'MELLO M. and ERISKSEN TH (2010) Software, sports day and sheera: Culture and identity processes within a global software organization in india. Information \& Organization, 20(2), 81-110.

DAS D, DHARWADKAR R and BRANDES P (2008) The importance of being 'Indian': Identity centrality and work outcomes in an off-shored call center in India. Human Relations 61(11), 1499-1530.

DIBBERN J, WINKLER J and HEINZL A (2008) Explaining Variations in Client Extra Costs between Software Projects Offshored to India. MIS Quarterly 32(2), 333-366.

DIRKS NB (2001) Castes of Mind: Colonialism and the Making of Modern India. Princeton University Press, New Jersey.

DIROMUALDO A and GURBAXANI V (1998) Strategic intent for IT outsourcing. Sloan Management Review 39(4), 67-80.

DOOLIN B and MCLEOD L (2005) Towards critical interpretivism in is research. In Handbook of critical information systems research: Theory and application (HOWCROFT D and TRAUTH EM, Eds), pp 244-271, Edward Elgar, Cheltenham.

DOSSANI R and KENNEY M (2007) The Next Wave of Globalization: Relocating Service Provision to India. World Development 35(1), 772-791.

DOSSANI R and KENNEY M (2009) Service Provision for the Global Economy: The Evolving Indian Experience. Review of Policy Research 26(5), 77-104.

Earl MJ (1996) The Risks of Outsourcing IT. Sloan Management Review 37(3), 26-32.

FOUCAULT M (1972) The Archaeology of Knowledge. Tavistock Publications (A. Sheridan, Trans.), London.

FRENKEL M (2008) The Multinational Corporation as a Third Space: Rethinking International Management Discourse on Knowledge Transfer through Homi Bhabha. Academy of Management Review 33(4), 924-942.

FRENKEL M and SHENHAV Y (2003) From Americanization to Colonization: The Diffusion of Productivity Models Revisited. Organization Studies 24(9), 1537-1561.

FRENKEL M and ShHENHAV Y (2006) From Binarism Back to Hybridity: A Postcolonial Reading of Management and Organization Studies. Organization Studies 27(6), 855-876.

FRIEDMAN T (2005) The World is Flat: A Brief History of the 21st Century. Farrar, Straus and Giroux, New York.

GARUD R and KUMARASWAMY A (2005) Vicious and Virtuous Circles in the Management of Knowledge: The Case of Infosys Technologies. MIS Quarterly 29(1), 9-33.

GEERTZ C (2000) Local knowledge: Further essay in interpretive anthropology. Basic Books, New York. 
GILROY P (1993) The black Atlantic: Modernity and double consciousness. Routledge, London.

GOO J, KISHORE R, RAO HR and NAM K (2009) The Role of Service Level Agreements in Relational Management of Information Technology Outsourcing: an Empirical Study. MIS Quarterly 33(1), 119-145.

GOPAL A, SIVARAMAKRISHNAN K, KRISHNAN MS and MUKHOPADHYAY T (2003) Contracts in Offshore Software Development: An Empirical Analysis. Management Science 49(12), 1671-1683.

GOSS J (1996) Postcolonialism: subverting whose empire? Third World Quarterly 17(2), 239-250.

GRAMSCI A (1971) Selections from the prison notebooks. Lawrence and Wishart, trans. Q. Hoare \& G. Nowell-Smith, London.

GROVER V, MYUN JC and TENG JTC (1996) The Effect of Service Quality and Partnership on the Outsourcing of Information Systems Functions. Journal of Management Information Systems 12(4), 89-116.

GUHA R (1989) Dominance without hegemony and its historiography. In Subaltern Studies (GUHA R, Eds), pp.210-309, Oxford University Press, New Delhi, India.

HAHN ED, DOH JP and BUNYARATAVEJ K (2009) The Evolution of Risk in Information Systems Offshoring: the Impact of Home Country Risk, Firm Learning, and Competitive Dynamics. MIS Quarterly 33(3), 597-616.

HEEKS RB (1990) Technology Policy Making as a Social and Political Process: Liberalizing India's Software Policy. Technology Analysis \& Strategic Management 2(3), 275.

HEEKS RB (1999) Software Strategies in Developing Countries. Communications of the ACM 42(6), 15-20.

HIRSCHHEIM RA, HEINZL A and DIBBERN J (2002) Information Systems Outsourcing: Enduring Themes, Emergent Patterns, and Future Directions. Springer-Verlag, Berlin.

HOFSTEDE G (1980) Culture’s Consequences. Sage Publications, Newbury Park: CA.

HUY QN (2011) How middle managers' group-focus emotions and social identities influence strategy implementation. Strategic Management Journal 32(13), 1387-1410.

JACK G, WESTWOOD R, SRINIVAS N and SARDAR Z (2011) Deepening, broadening and re-asserting a postcolonial interrogative space in organization studies. Organization 18(3), 275-302.

JAIN RP, SIMON JC and POSTON RS (2011) Mitigating Vendor Silence in Offshore Outsourcing: An Empirical Investigation. Journal of Management Information Systems 27(4), 261-298. 
JOSHI KK and MUDIGONDA SS (2008) An analysis of India's future attractiveness as an offshore destination for IT and IT-enabled services. Journal of Information Technology 23(4), 215-227.

KAPOOR I (2002) Capitalism, culture, agency: dependency versus postcolonial theory. Third World Quarterly 23(4), 647-664.

KHILNANI S (1997) The Idea of India. Hamish Hamilton, London.

KLEIN HK and MYERS MD (1999) A Set of Principles for Conducting and Evaluating Interpretive Field Studies in Information Systems. MIS Quarterly 23(1), 67-93.

KRISHNA S, SAHAY S and WALSHAM G (2004) Managing Cross-Cultural Issues in Global Software Outsourcing. Communications of the ACM 47(4), 62-66.

KSHETRI N and DHOLAKIA N (2009) Professional and trade associations in a nascent and formative sector of a developing economy: A case study of the NASSCOM effect on the Indian offshoring industry. Journal of International Management 15(2), 225-239.

KUUS M (2004) Europe's eastern expansion and the re-inscription of otherness in EastCentral Europe. Progress in Human Geography 28 (4), 472-489.

KVASNY L and RICHARDSON H (2006) Critical research in information systems: looking forward, looking back. Information Technology \& People 19 (3), 196-202.

KWEK D (2003) Decolonizing and Re-Presenting Culture's Consequences: A Postcolonial Critique of Cross-Cultural Studies in Management. In Postcolonial Theory and Organizational Analysis: A Critical Engagement (PRASAD A, Eds), pp.121-146, Palgrave Macmillan, New York.

LACITY M and HIRSCHHEIM R (1995) Beyond the Information Systems Outsourcing Bandwagon: The Insourcing Response. John Wiley and Sons, New York.

LACITY MC and WILLCOCKS LP (2001) Global Information Technology Outsourcing: In Search of Business Advantage. John Wiley and Sons, Chichester.

LACITY MC and RUDRAMUNIYAIAH PS (2009) Funny Business: Public Opinion of Outsourcing and Offshoring as Reflected in U.S. and Indian Political Cartoons. Communications of AIS 2009(24), 199-224.

LEE AS (1991) Integrating Positivist and Interpretive Approaches to Organizational Research. Organization Science 2(4), 342-365.

LEVINA N and ROSS JW (2003) From the Vendor's Perspective: Exploring the Value Proposition in Information Technology Outsourcing. MIS Quarterly 27(3), 331-364.

LEVINA N and VAAST E (2008) Innovating Or Doing as Told? Status Differences and Overlapping Boundaries in Offshore Collaboration. MIS Quarterly 32(2), 307-332.

LOOMBA A (1998) Colonialism/Postcolonialism. Routledge, London. 
LUNGA VB (2008) Postcolonial Theory: A Language for a Critique of Globalization? Perspectives on Global Development \& Technology 7(3), 191-199.

McKENNA S (2011) A critical analysis of North American business leaders' neocolonial discourse: global fears and local consequences. Organization 18(3), 387-406.

McMILLIN D (2006) Outsourcing Identities. Call Centres and Cultural Transformation in India. Economic and Political Weekly, 41(3), 235-241.

MEHTA N and MEHTA A (2009) Reducing Client Risks from Offshore it Vendors' $\mathrm{Hr}$ Challenges. MIS Quarterly Executive 8(4), 191-201.

MIR R and MIR A (2009) From the Colony to the Corporation Studying Knowledge Transfer Across International Boundaries. Group \& Organization Management 34(1), 90-113.

MIRCHANDANI K (2004) Practices of global capital: Gaps, cracks and ironies in transnational call centres in India. Global Networks 4(4), 355-373.

MUDAMBI R and VENZIN M (2010) The Strategic Nexus of Offshoring and Outsourcing Decisions R. Mudambi and M. Venzin Offshoring and Outsourcing Decisions. Journal of Management Studies 47(8), 1510-1533.

MYERS MD (1997a) Interpretive Research Methods in Information Systems. In Information Systems: An Emerging Discipline (MINGERS J and STOWELL F, Eds), pp.239-266, McGraw Hill London.

MYERS MD (1997b) Qualitative Research in Information Systems. MIS Quarterly 21(2), 241-242.

MYERS MD (1999) Investigating Information Systems with Ethnographic Research. Communications of the AIS (2) 23, pp. 1-20.

MYERS MD and KLEIN HK (2011) A Set of Principles for Conducting Critical Research in Information Systems. MIS Quarterly 35(1), 17-36.

NASSCOM (2012) The IT-BPO Sector in India: Strategic Review 2012. www.nasscom.org/sites/default/files/researchreports/SR_2012_Executive_Summary.pdf, accessed 10 March 2012.

NICHOLSON B and SAHAY S (2004) Embedded knowledge and offshore software development. Information \& Organization 14(4), 329-365.

NILEKANI N (2009) Imagining India: The Idea of a Nation. Penguin Press, New York.

OSHRI I, KOTLARSKY J and WILLCOCKS L (2007) Managing Dispersed Expertise in it Offshore Outsourcing: Lessons from Tata Consultancy Services. MIS Quarterly Executive 6(2), 53-65.

ÖZKAZANÇ-PAN B (2008) International Management Research Meets "The Rest of the World". Academy of Management Review 33(4), 964-974. 
PELTONEN T (2006) Critical Theoretical Perspectives on International Human Resource Management. In Handbook of Research in International Human Resource Management (STAHL GK and BJORKMAN I, Eds), pp. 523-535, Edward Elgar, Cheltenham, UK.

POSTER WR (2007) Who's On the Line? Indian Call Center Agents Pose as Americans for U.S.-Outsourced Firms. Industrial Relations 46(2), 271-304.

PRASAD A and PRASAD P (2003) The Empire of Organizations and the Organization of Empires: Postcolonial Considerations on Theorizing Workplace Resistance. In Postcolonial Theory and Organizational Analysis (PRASAD A, Eds), pp.95-120, Palgrave, London.

PRASAD A (2003) Postcolonial Theory and Organizational Analysis: A Critical Engagement. Palgrave Macmillan, New York.

QUAYSON A (2000) Postcolonialism: Theory, Practice or Process? Polity Press, Cambridge.

RAMESH B (2004) "Cyber Coolies" in BPO. Insecurities and Vulnerabilities of NonStandard Work. Economic and Political Weekly, 39(5), 492-497.

RAVISHANKAR MN and PANSL SL (2008) The influence of organizational identification on organizational knowledge management (KM). Omega 36(2), 221-234.

RAVISHANKAR MN, PAN SL and LEIDNER DE (2011) Examining the Strategic Alignment and Implementation Success of a KMS: A Subculture-Based Multilevel Analysis. Information Systems Research 22(1), 39-59.

RICHARDSON H and ROBINSON B (2007) The mysterious case of the missing paradigm: a review of critical information systems research 1991-2001. Information Systems Journal 17(3), 251-270.

SAID E (1978) Orientalism. Pantheon Books, New York.

SAUNDERS C, GEBELT M and HU Q (1997) Achieving Success in Information Systems Outsourcing. California management review 39(2), 63-79.

SHIMONI B (2006) Cultural borders, hybridization, and a sense of boundaries in Thailand, Mexico, and Israel. Journal of Anthropological Research, 62(2) 217-234.

SPIVAK GC (1988) Can the subaltern speak? In Marxism and the interpretation of Culture (NELSON C and GROSSBERG L, Eds), pp. 271-313, University of Illinois Press, Urbana, USA.

SPIVAK GC (1999) A Critique of Postcolonial Reason. Harvard University Press, Cambridge, MA, USA.

UPADHYA C (2009) Controlling offshore knowledge workers: Power and agency in India's software outsourcing industry. New Technology, Work \& Employment 24(1), 2-18. 
VAN MAANEN J (1979) The Fact of Fiction in Organizational Ethnography. Administrative Science Quarterly 24(4), 539-550.

VARMAN R and SAHA B (2009) Disciplining the discipline: understanding postcolonial epistemic ideology in marketing. Journal of Marketing Management 25(7), 811-824.

WALSHAM G (1995a) The Emergence of Interpretivism in IS Research. Information Systems Research 6(4), 376-394.

WALSHAM G (1995b) Interpretive case studies in IS research: nature and method. European Journal of Information Systems 4(2), 74-81.

WILLCOCKS L and GRIFFITHS C (2010) The Crucial Role of Middle Management in Outsourcing. MIS Quarterly Executive 9(3), 177-193.

YOUNG RJC (2001) Postcolonialsm: An Historical Introduction. Blackwell Publishers, Oxford.

ZAIDMAN N and BROCK DM (2009) Knowledge Transfer Within Multinationals and Their Foreign Subsidiaries: A Culture-Context Approach. Group \& Organization Management 34(3), 297-329.

ZEITLIN J (2000) Introduction: Americanization and its limits: Reworking US technology and management in post-war Europe and Japan. In Americanization and its limits:Reworking US technology and management in post-war Europe and Japan (ZEITLIN J and HERRIGEL G, Eds), pp. 1-52. Oxford University Press, Oxford, UK.

ZIMMERMANN A and RAVISHANKAR MN (2011) Collaborative IT offshoring relationships and professional role identities: Reflections from a field study. Journal of Vocational Behaviour, 78(3), 351-360. 